\title{
Mobile Web-Based Character Building for Enhancement of Student Character at Elementary Schools: An Empirical Evidence
}

\author{
https://doi.org/10.3991/ijim.v15i21.24959 \\ Arita Marini ${ }^{1(凶)}$, Desy Safitri ${ }^{1}$, Ika Lestari ${ }^{1}$, Yustia Suntari ${ }^{1}$, Sri Nuraini ${ }^{1}$, Maratun \\ Nafiah $^{1}$, Saipiatuddin ${ }^{1}$, Wahyu Sri Ambar Arum ${ }^{1}$, Ajat Sudrajat ${ }^{2}$, Rossi Iskandar ${ }^{3}$ \\ ${ }^{1}$ Universitas Negeri Jakarta, Jakarta, Indonesia \\ ${ }^{2}$ Universitas Terbuka, Tangerang Selatan, Indonesia \\ ${ }^{3}$ Universitas Trilogi, Jakarta, Indonesia \\ aritamarini@unj.ac.id
}

\begin{abstract}
This study aims to examine the effect of mobile web-based character building on enhancing student character. This study used an experimental research design. The population used in this study is elementary school students in the Cilincing district in North Jakarta in Indonesia. This research sample was taken randomly using the Slovin formula consisting of 192 students consisting of the experimental and control group. The data analysis approach in this study used the t-test for the inferential statistic to test the hypothesis in this research. The literature review covers 76 studies, and in conclusion, it is clear that the mobile web has a positive influence on student performance. However, some studies have presented that there is only a minor impact. Mobile web-based character-building developed in this study consists of integrating the values of character at the beginning, the core, and the end of class activity. Student character is estimated by measuring student inclination to learning, persistence, and student judgment. This study finds that the experimental group posttest for 192 students achieved 36.92 larger than the control group of 24.78 with the t-test of 0.006 , which is smaller than 0.05 . This study concludes that mobile web-based on character-building supports student character at elementary school of Cilincing district in North Jakarta in Indonesia. The contribution of this study is to build students' personalities so that they can become individuals beneficial to themselves and their surroundings.
\end{abstract}

Keywords-mobile web, character building, student character

\section{$1 \quad$ Introduction}

Education is an effort to improve student's ability to have noble characters and live independently better. In this millennial generation, the world has entered the digital revolution or industrial revolution 4.0. The use of technology will change human life patterns. In the current digital era, industry 4.0 provides many conveniences and opens 
opportunities, especially for students. Information becomes more quickly accepted and widely disseminated. Through such a situation, the potential challenges become increasingly diverse. Various socio-cultural values come without a hitch. Differences in physical, cultural, and thought are also more easily visible. The differences that exist can be complementary and strengthen unity.

On the other hand, it can trigger division. Based on the opportunities, challenges, and threats of the current digital era, it makes people aware that the role of education is not only to educate but also to integrate character values in all aspects of education. In this digital era, the optimal use of technology is the primary key for integrating the character values of the students. Having declined in morals, knowledge, and positive characters of the students are due to deviation use of technology and the internet. Therefore, the urgency of character building needs to be considered for the students in this digital era.

Many types of research related to the technology application in education have been done in the current years. The students with individual differences influence their thoughts towards the use of technology [1-6]. Social factors and cultural practices are essential to affect the students taking advantage of using technology. Furthermore, technology can also enhance student educational outcomes and improve social skills with others. Cultural habits have an impact on how the students make use of technology. Technological development allows the students to get involved optimally and to acquire the material given effectively. The use of technology is appropriate for improving the student's thinking skills. Another study found that some students face obstacles in using technology [7]. Improvement motivation approach can assist the students in controlling threats of utilizing technology and raise student learning outcomes. Student willingness to technology is associated with self-regulation skills, satisfaction, and learning outcomes [8]. The student's readiness for using technology significantly supports self-regulation skills to stimulate satisfaction and academic achievements. A similar study found a positive attitude towards technology by enhancing reading comprehension skills [9]. This study highlights that utilization of technology can ultimately stimulate higher-order thinking skills. The application of technology in class can be used to assess students' cognitive aspects [10]. Further, this study suggests that student learning performance and classroom dynamics can be raised by applying technology. However, previous studies conducted focused on relationships between using technology and the cognitive aspects of the students. So that the students can wisely use technology in industrial revolution 4.0, character education is very urgent to be frequently implemented. Therefore, it is essential to conduct this study by combining technology with character-building, shaping students' noble behavior. This study developed mobile web-based character building and found out how to use this technology to improve fifth-grade elementary school student character at Cilincing district in North Jakarta as part of Indonesia. We primarily posed the question in this research as follows: "Is there any effect of mobile web-based character building on fifth-grade elementary school student character?". This study is an effort to respond to the problems as follows:

a) How to develop mobile web-based character building?

b) Were there any differences in the posttest of the positive character of the students because of applying mobile web-based on character education? 
Our research combined the mobile web and character education for students. Further, we will describe the advantages of utilizing the mobile web in education, including its impact on student competencies and other aspects. In addition, character-building by integrating many kinds of character values will also be presented related to the improvement of student character.

In this research, there are 76 literature reviews covered. This literature was selected based on its overview of current, relevant, and comprehensive publications related to the research questions posed in this research. In this literature review, we do analysis, synthesis, and critical evaluation to come up with a clear picture of the theme of this study and have to be assured to reflect the current state of the art.

\subsection{Mobile apps in education}

Technology can enhance student academic achievement [11-12]. Many recent studies related to mobile technology were conducted to improve learning quality. This study means that learning with technology has some benefits, including its portability and being free from geographic obstacles. Hence, it is essential to improve its implementation to foster student engagement in learning by giving wider collaborative opportunities and easily accessible information. The student habits can be developed related to learning efficiency. These acts are considered that technology would also be relied on to distribute information and enhance the students' literacy as a tool for proficiency construction. It is noteworthy that mobile learning can raise student ability in entrepreneurship [13]. In this sense, mobile technology drives student entrepreneurial competence, stimulating students to anticipate outside the box. The finding highlights that it is fundamental to raise student entrepreneurial competencies through introducing mobile learning platforms completed with their opportunities and challenges. Furthermore, technology can solve the problem of preparing the students to have a creative mindset, and energetic behavior is urgent for success. The results also include that these technological solutions can encourage student-centered learning and creativity.

Mobile learning applications can control usability issues [14]. This technology is designed suitable with students' needs according to their skills. Thus, this application can help the students to develop their communication and interaction skills. This study shows that technology's advancement makes it convenient and efficient to the individuals supported by its utilization. There is a uniqueness of characteristics in each mobile apps for education providing its services [15]. These tools are the most common and encouraging approach to engage the students in learning and reinforcing their capacities. There are some benefits due to the advancement of educational apps involving the students who do not feel it is necessary to spend their time and money finding the learning resources. Mobile technology called Mobile-Assisted Mind Mapping Technique can encourage student writing skill performance [16]. This tool is very supportive, utilizing mind mapping to enhance student argumentative writing competencies and help students create interpretations and rationalize argumentative writing. It is interesting to note that using this technology can stimulate students' creativity by brainstorming their ideas, visualizing their thoughts, and communicate them to others. In other words, technology can encourage a free flow of students' ideas, making an ideal brainstorming format. 
Further, learning using the website can enhance the students' learning activities [17]. It is indicated that this model can develop student knowledge acquisition leading to a higher increase in conceptual and experimental knowledge. It is explicitly highlighted that this model offers the students unparalleled access to learning resources. Interestingly, applying this model makes learning experiences being open, flexible, providing chances for engaging, interactive, and efficient learning. The pervasiveness of applying websites can bridge classroom learning to the real world in contextualizing learning. Regarding the learning process, this is vital to establish that this technology allows for adjustability by omitting the urgency for learning to occur at a particular time and place. Most importantly, it is essential that mobile learning seems logically combine learning into students' daily routine resulting in knowledge retention.

\section{$1.2 \quad$ Student character}

There are many studies related to offering a character-building model. One study confirmed that character education in extracurricular activities was done by implementing simulation games [18]. This study highlighted that character values integrated into extracurricular activities include discipline, independence, health, sportiveness, creativity, cooperation, sportsmanship, and self-confidence. It is worth noting that the importance of character value integration in extracurricular activities can be included in non-formal educational activities. Moreover, this activity benefits students to form positive student behavior, including the students' morals. Another study confirmed the effectiveness of teaching strategy on student affective domain [19-22]. It is presented that the implementation of cooperative learning methods can promote a positive student attitude. This result is incredibly accurate that possessing positive attitudes encourage positive behavior towards learning. Despite these facts, there is no information provided about examining the teaching method implemented to kinds of character values integrated.

The teaching-learning process plays an essential role in upgrading empathy levels [23-37]. The existing literature reports that a creative mind in educational efforts of experience in community problems can positively affect student sympathy. In this sense, highly interactive activities with lived experience can develop empathetic student skills for ongoing advantages outside the classroom.

Many factors are influencing the social skills of the students [38-42]. Internal and external factors predict solidarity, empathy, conversational, self-assertion, collaboration, and conflict resolution skills of the student. These factors can improve or diminish student interpersonal skills. The teachers can stimulate student social skills by using the appropriate teaching method, including group discussion and a team-based project. The students can develop their communication skills, respect others by listening, openness towards diversity, collaboration, and adaption. Character education can also be conducted by using stop motion animation [43-44]. The developed stop motion animation can be linked to personality building in-class activities, school atmosphere, extracurricular activities, and society's participation. Many character values can be integrated involving discipline, religious personality, honesty, nationalism. Nevertheless, the existing literature has not been generated in detail about applying technology related to positive student character. Our research adds to the extant literature by 
focusing on creating character building based on mobile web for students at elementary schools and building character through the mobile web to enhance student character.

\section{Method}

This research was carried out for 192 fifth-year students at elementary schools of Cilincing district in North Jakarta in Indonesia for experimental and control groups.

\subsection{Student character}

The research used an experimental design which can be seen in Table 1. In the group experiment, mobile web-based character building was applied. In this research, there are different treatments provided for groups of experiment and control. There is no treatment for the control group. Table 1 presents the design of this research.

Table 1. Design of experimental research of mobile web-based character building

\begin{tabular}{|l|c|c|}
\hline E & $\mathrm{X}$ & $\mathrm{O}_{1}$ \\
\hline $\mathrm{C}$ & - & $\mathrm{O}_{2}$ \\
\hline
\end{tabular}

Notations:

$\mathrm{E}=$ Experimental

$\mathrm{C}=$ Control

$\mathrm{O}_{1}=$ Experimental Posttest

$\mathrm{O}_{2}=$ Control Posttest

$\mathrm{X}=$ Character building based on mobile-web

\subsection{Population and sample}

This research comprises elementary school students in the Cilincing district in North Jakarta in Indonesia as population. This research withdrew a sample randomly involving 192 students for each group of experimental and control.

\subsection{Instruments of research}

This research utilized a posttest instrument associated with student character involving student inclination to learning, persistence, and student judgment. After providing treatment in experimental, posttest was given to the group. The control group serves as a comparison with the experimental group given treatment. The comparison between the posttest of the two groups indicates the treatment effect delivered.

\subsection{Data analysis}

In statistical analysis, a normality test was done. A test of Kolmogorov-Smirnov was conducted for testing data distribution normality. Levene's test was used for data 
homogeneity. In this study, inferential statistics for hypothesis testing used the t-test. Hypothesis decisions were made utilizing criteria with a 0.05 significance level. If the test statistic is more extreme than the critical value, the null hypothesis was rejected. On the contrary, the hypothesis of null fails to be rejected if the test is less extreme.

\section{$3 \quad$ Results and discussions}

\subsection{Mobile web-based character building}

Mobile web-based character building was design using $8 \mathrm{~b}$ as a professional web. $8 \mathrm{~b}$ has sections with standards and is so sensitive that mobile web content is ideal for smartphones. Google accelerates for $8 \mathrm{~b}$ as Mobile Pages based on the web being an HTML framework which is open-source on which page can be loaded in the mobile web which is quicker if it is opened through smartphones. Accommodating to support web that is mobile to make faster, the designs of $8 \mathrm{~b}$.com comprise many kinds of categories. The template of 8 b.com has many current configurations and types which are up-to-date. This mobile web utilized the 'consulting' template category. Some buttons are essential on the editor page related to adding, deleting, editing sections, etc.

There are five menu bars on the main page of mobile web-based character building: home, background, documentation, legal basis, and objectives. The home menu offers contact person, welcome page, the guidance titles of character building leading to other pages explaining in detail. Some 2D animation video menus are related to character building at the bottom of this main page. These animated videos tell about the way character values are assimilated in the classroom.

The background page shows the rationality of this product providing instructions for elementary school teachers to integrate character values in class from the beginning until the closing activities of the teaching-learning process. Furthermore, it is expected that implementing mobile web-based character building can improve teacher competencies to instill character values in class to build students' positive characters.

On the documentation page, it can be seen activities of inculcating sportsmanship values in physical education and health class at elementary schools. In addition, the user also can see the activities of cultivating religious culture through praying before class begins. Other activities shown on this page are promoting student creativity by using the environment as a learning source, fostering productivity value through displaying student work, introducing nationalism value by singing national anthems, and an open library where students can borrow and return books by taking notes by themselves.

\subsection{Mobile web-based character-building impact on student character}

Table 2 presents normality results for 192 students as the sample for the control and experiment groups. Mean as the measurement of normal parameters as the distribution central tendency and variability measurement of standard deviation arriving at 24.780 and 4.404 for the control group posttest and 36.920 and 4.041 for experimental group posttest. Table 2 also displays that the value of Kolmogorov-Smirnov in the posttest of the control group achieved 0.197 and experimental group 0.130 bigger than 0.05 . The 
posttest calculated value of Kolmogorov-Smirnov demonstrated by the absolute score in highest differences for the control and experimental class attained 0.078 and 0.084 smaller than 0.0981 of table values in the Kolmogorov-Smirnov. The findings show that the posttests in the control and experimental groups have a normal distribution for statistical analysis. This measurement can increase research objectivity and keep away from intolerance.

Table 2. Test of Kolmogorov-Smirnov

\begin{tabular}{|l|l|c|c|}
\hline \multicolumn{2}{|c|}{} & Experiment & Control \\
\hline \multirow{2}{*}{ N } & Mean & 192 & 192 \\
\cline { 2 - 4 } & Std. Deviation & 24.780 & 36.920 \\
\hline \multirow{3}{*}{ Most Extreme Differences } & Absolute & 4.404 & 4.041 \\
\cline { 2 - 4 } & Positive & .078 & .084 \\
\cline { 2 - 4 } & Negative & .077 & .077 \\
\hline Kolmogorov-Smirnov Z & -.078 & -.084 \\
\hline Asymp. Sig. (2-tailed) & 1.076 & 1.170 \\
\hline
\end{tabular}

In Table 3, Levene's test using $\mathrm{df} 1=1$ and $\mathrm{df} 2=382$ in the posttest is 0.061 greater than 0.05 . This measurement indicates that the variance level of experimental and control groups is unchanging over the sample; therefore, the probability values are reliable.

Table 3. Test of variances homogeneity

\begin{tabular}{|c|c|c|c|}
\hline Levene Statistic & df1 & df2 & Sig. \\
\hline 3.539 & 1 & 382 & .061 \\
\hline
\end{tabular}

Table 4 shows group statistics indicating that the experimental group's posttest for 192 students achieved 36.92 more than the posttest for the control group of 24.78. It can be confirmed that statistically, the descriptive difference exists between posttest in experiment and control class. Table 5 is necessary to prove the significance of this difference.

Table 4. Descriptive statistics

\begin{tabular}{|l|c|c|c|c|}
\hline \multicolumn{1}{|c|}{ Group } & N & Mean & Standard Deviation & Standard Error Mean \\
\hline Control & 192 & 24.78 & 4.404 & 0.318 \\
\hline Experiment & 192 & 36.92 & 4.041 & 0.292 \\
\hline
\end{tabular}

It can be explained that experimental posttests are significantly different from control ones. The t-test of posttest data in experimental and control groups seen in Table 4 reached 0.006 smaller than 0.05 . Further, the calculated t-values for the posttest of both groups arrive at 1.622 . Based on these measurements, it can be confirmed that the hypothesis of null is rejected. 
Table 5. t-test in posttests of experiment and control

\begin{tabular}{|c|c|c|c|c|c|c|c|c|}
\hline \multicolumn{2}{|c|}{$\begin{array}{l}\text { Levene's Test } \\
\text { for Equality of } \\
\text { Variances }\end{array}$} & \multicolumn{7}{|c|}{ t-test for Equality of Means } \\
\hline \multirow[t]{2}{*}{$\mathbf{F}$} & \multirow[t]{2}{*}{ Sig. } & \multirow[t]{2}{*}{$\mathbf{t}$} & \multirow[t]{2}{*}{ df } & \multirow[t]{2}{*}{$\begin{array}{c}\text { Sig. } \\
\text { (2-tailed) }\end{array}$} & \multirow[t]{2}{*}{$\begin{array}{c}\text { Mean } \\
\text { Difference }\end{array}$} & \multirow[t]{2}{*}{$\begin{array}{l}\text { Std. Error } \\
\text { Difference }\end{array}$} & \multicolumn{2}{|c|}{$\begin{array}{l}95 \% \text { Confidence } \\
\text { Interval of the } \\
\text { Difference }\end{array}$} \\
\hline & & & & & & & Lower & Upper \\
\hline 3.539 & 0.061 & 28.133 & 382 & .000 & -12.135 & .431 & -12.984 & -11.287 \\
\hline
\end{tabular}

In Table 5, it can be shown that Levene's test attained 0.061 larger than 0.05 proving that data variance of the experimental and control group is homogenous so that interpretations of independent samples test output can be guided by the score in equal variances assumed. It can be inferred that the posttest in the experiment has a significant difference from the one in control. Table 5 also displays that the mean difference reached -12.135 indicating the difference between posttest in the experiment and control group from -12.984 to -11.287 . The calculated t value achieved 28.133 larger than the $t$ table of 1.1960, indicating a difference of posttests in the experimental and control groups.

Based on findings, it can be interpreted that the implementation of mobile webbased character-building positively influences student character at elementary schools at Cilincing District in North Jakarta in Indonesia. This study confirms that applying mobile web-based character building can develop the upbeat personalities of the students. This result is consistent with the study presenting that the character-building model can enhance student positive behavior [45-47]. Model of character building based on assessing the quantity of attendance, the steadiness of submitting the assignments, hindering violent behavior, student participation in school cooperation, and non-academic culture. Similar to the study finding the model character education related to school culture [48-49]. It is highlighted that religious, honest, discipline, clean and healthy school culture stimulate character-building conducted through school culture.

Further, character-building on the mobile web-related teaching-learning process can upgrade the positive character of the students [50-54]. Character-building guidance for the teachers involves integrating values of character in the classroom. Implementation of character education guidance on the website can increase student positive behavior [55-56]. The direction of character value integration at school can enhance student achievement, motivational and social-emotional behavior. In addition, the classroom action research to follow the character-building guidance provided can raise a positive student attitude [57]. Character building through school culture can develop positive student character. The use of an e-learning model can enhance student character [58]. Building character values involving honest and discipline characters can be done through student worksheets with an e-learning model.

Moreover, technology plays a role in character building for the students [59-64]; implementing technology forms students' character, including morality, discipline, tolerance, and cooperation. Besides, student character can be developed through using blended learning [65]. It is believed that this method can integrate character values 
comprising communication, creativity, curiosity, and hard work in the teaching-learning process in math class. Technology implementation can enhance students' character [66]. Student characters developed through using technology are mutual help, social solidarity, tolerance, community sense, collective sense, and collaboration. The teacher's skills to apply technology to improve students' character play a crucial role. Teachers' competencies to effectively run this method cannot be ignored.

\section{Conclusion}

Based on the posttest for the experimental group, given that the treatment of applying mobile-web-based character building is larger than the posttest of the control group had no treatment with a statistically significant difference. We conclude that mobile web-based character-building implementation positively affects the enhancement of student character at Cilincing District. This tool explains the guidance for elementary school teachers to be applied at school to effectively implement character education for the teaching-learning process, including the beginning, core, and closing activities. Moreover, the guidance of applying the character value of sportsmanship integrated into physical education and health class is also attached on this mobile web. Besides, the values of character combined in the school's culture, including religion, honesty, working ethos, and nationalism, are provided on this mobile web. The teachers implementing the guidance effectively how to integrate character values at school positively affect students' lives positive character.

Further research can be recommended that this character building based on the mobile web can encourage student behavior at elementary schools in all regions of Jakarta. This study aims to guide elementary school teachers about integrating character values in the teaching-learning process towards meaningful learning for the students. The limitation of this study is that this research only covers elementary school students in East Jakarta. It is recommended that further research should also include North, South, Central, and West regions in Jakarta to find out comprehensively about technology advancement's influence on character education.

\section{$5 \quad$ Acknowledgment}

Ministry of Education, Culture, Research, and Technology Republic Indonesia supported this research specifically for decentralization research grants. Further, we appreciate those who have helped to collect data in this research.

\section{References}

[1] Hunaiyyan, H., A., Alhajri, R., Sharhan, S., A., \& Bimba, A. Human-computer interaction perspective on mobile learning: Gender and social implications. International Journal of Interactive Mobile Technologies, 15(11), 4-20, 2021. https://doi.org/10.3991/ijim. $\underline{\mathrm{v} 15 \mathrm{i} 11.21367}$ 
[2] Papadakis, S. Tools for evaluating educational apps for young children: A systematic review of the literature. Interactive Technology and Smart Education, 18(1), 18-49, 2021. https:// doi.org/10.1108/ITSE-08-2020-0127

[3] Papadakis, S. Apps to promote computational thinking concepts and coding skills in children of preschool and pre-primary school age. Mobile Learning Applications in early childhood education, 101-121, 2020. https://doi.org/10.4018/978-1-7998-1486-3.ch006

[4] Ampartzaki, M., Kalogiannakis, M., \& Papadakis, S. (2021). Deepening Our Knowledge about Sustainability Education in the Early Years: Lessons from a Water Project. Education Sciences, 11(6), 251. https://doi.org/10.3390/educsci11060251

[5] Vidakis, N.,Barianos,A., K., Trampas,A.,M.,Papadakis, S., Kalogiannakis,M., \& Vassilakis,K. (2019, May). in-Game Raw Data Collection and Visualization in the Context of the "ThimelEdu" Educational Game. In International Conference on Computer Supported Education (pp. 629-646). Springer, Cham. https://doi.org/10.1007/978-3-030-58459-7 30

[6] Poultsakis, S., Papadakis, S., Kalogiannakis, M., \& Psycharis, S. (2021). The management of Digital Learning Objects of Natural Sciences and Digital Experiment Simulation Tools by teachers. Advances in Mobile Learning Educational Research, 1(2), 58-71. https://doi. org/10.25082/AMLER.2021.02.002

[7] Nguyen, H., T., T. Boosting motivation to help students to overcome online learning barriers in covid-19 pandemic: A case study. International Journal of Interactive Mobile Technologies, 15(10), 4-20, 2021. https://doi.org/10.3991/ijim.v15i10.20319

[8] Yavuzalp, N., \& Bahcivan, E. A structural equation modeling analysis of relationships among university students' readiness for e-learning, self-regulation skills, satisfaction, and academic achievement. Research and Practice in Technology Enhanced Learning, 16(15), 1-17, 2021. https://doi.org/10.1186/s41039-021-00162-y

[9] Samiei, F., \& Ebadi, S. Exploring EFL learners' inferential reading comprehension skills through a flipped classroom. Research and Practice in Technology Enhanced Learning, 16(12), 1-18, 2021. https://doi.org/10.1186/s41039-021-00157-9

[10] Wang, A., I., \& Tahir, R. The effect of using Kahoot! for learning - A literature review. Computers \& Education, 149, 1-22, 2020. https://doi.org/10.1016/j.compedu.2020.103818

[11] Zang, X. Mobile-assisted writing instruction: Affordances, challenges, and future directions. International Journal of Interactive Mobile Techologies, 15(10), 194-207, 2021. https://doi. org/10.3991/ijim.v15i10.21519

[12] Tretyakova, N., Lyzhin, A., Chubarkova, E., Uandykova, M., \& Lukiyanova, M. Mobile-learning platform for the development of entrepreneurial competences of the students. International Journal of Interactive Mobile Techologies, 15(9), 118-135, 2021. https://doi.org/10.3991/ijim.v15i09.20225

[13] Ghabban, F., M., Hajjar, M., and Alharbi, A. Usability evaluation and user acceptance of mobile applications for Saudi Autistic children. International Journal of Interactive Mobile Techologies, 15(7), 30-46, 2021. https://doi.org/10.3991/ijim.v15i07.19881

[14] Mkpojlogu, E., O., C., Hussain, A., \& Agbudu, M., O. Security issues in the use of mobile educational apps: A review. International Journal of Interactive Mobile Techologies, 15(6), 124-137, 2021. https://doi.org/10.3991/ijim.v15i06.20631

[15] Tsoukos, S., Lazos, P., Tzamalis, P., Kateris, A., \& Velentzas, A. How effectively can students' personal smartphones be used as tools in physics labs? International Journal of Interactive Mobile Techologies, 15(14), 55-71, 2021. https://doi.org/10.3991/ijim.v15i14.22375

[16] Elmabaredy, A., Elkholy, E., \& Tolba, A., A. Web-based adaptive presentation techniques to enhance learning outcomes in higher education. Research and Practice in Technology Enhanced Learning, 15(20), 1-18, 2021. https://doi.org/10.1186/s41039-020-00140-W 
[17] Fabian, K., Topping, K., J., \& Barron, I., G. Using mobile technologies for mathematics: Effects on student attitudes and achievement. Educational Technology Research and Development, 66, 1119-1139, 2018. https://doi.org/10.1007/s11423-018-9580-3

[18] Chan, Y., N., Choy, Y., S., To, T., M., \& Lai, T., M. Influence of classroom soundscape on learning attitude. International Journal of Instruction, 14(3), 341-358, 2021. https://doi. org/10.29333/iji.2021.14320a

[19] Hand, M. Symposium on Michael Hand's a theory of moral education. Journal of Beliefs \& Values: Studies in Religion \& Education, 41(2), 227-228, 2020. https://doi.org/10.1080/13 617672.2020 .1717222

[20] Jerome, L., \& Kisby, B. Lessons in character education: Incorporating neoliberal learning in classroom resources. Critical Studies in education, 1-16, 2020. https://doi.org/10.1080/175 08487.2020 .1733037

[21] Sugano, S., G., C., \& Mamolo, L., A. The effects of teaching methodologies on students' attitude and motivation: A meta-analysis. International Journal of Instruction, 14(3), 827-846, 2021. https://doi.org/10.29333/iji.2021.14348a

[22] Boele, S., Van der Graaff, J., de Wied, M., Van der Valk, I. E., Crocetti, E. \& Branje, S. Linking parent-child and peer relationship quality to empathy in adolescence: A multilevel meta-analysis. Journal of Youth and Adolescence, 48, 1033-1055, 2019. https://doi. org/10.1007/s10964-019-00993-5

[23] Clark, M., A., Robertson, M., M., \& Young, S. I feel your pain: A critical review of organizational research on empathy. Journal of Organizational Behavior, 40(2), 166-192, 2018. https://doi.org/10.1002/job.2348

[24] Dawbin, B., Sherwen, M., Dean, S., Donnelly, S., \& Cant, R. Building empathy through a design thinking project: A case study with middle secondary schoolboys. Issues in Educational Research, 31(2), 440-457, 2021. http://www.iier.org.au/iier31/dawbin.pdf

[25] Cam, P. Review of a theory of moral education. Journal of Philosophy in Schools, 6(1), 116-120, 2019. https://doi.org/10.21913/JPS.v6i1.1570

[26] Clayton, M., \& D. Stevens. The poverty of contractarian moral education. Journal of Moral Education, 48(4), 501-514, 2019. https://doi.org/10.1080/03057240.2019.1576123

[27] D'Olimpio, L. Moral education within the social contract: whose contract is it anyway? Journal of Moral Education, 48(4), 515-528, 2019. https://doi.org/10.1080/03057240.2019. $\underline{1580565}$

[28] de Ruyter, D. Does a theory of moral education need the input of empirical research? Journal of Philosophy of Education, 53(4), 642-648, 2019. https://doi.org/10.1111/jope.v53.4

[29] Drerup, J. Review of a theory of moral education." Educational Theory, 68(4-5), 577-583, 2019. https://doi.org/10.1111/edth.12336

[30] Hambrick, K. Review of a theory of moral education. Educational Philosophy and Theory, 52(3), 322-326, 2019. https://doi.org/10.1080/00131857.2019.1625767

[31] Maxwell, B. Review of a theory of moral education. Theory and Research in Education, 17(1): 112-116, 2019. https://doi.org/10.1177/1477878519833748

[32] Peterson, A. Review of a theory of moral education. British Journal of Educational Studies, 67(1), 136-138, 2019. https://doi.org/10.1080/00071005.2018.1529957

[33] Levett-Jones, T., Cant, R., \& Lapkin, S. A systematic review of the effectiveness of empathy education for undergraduate nursing students. Nurse Education Today, 75, 80-94, 2019. https://doi.org/10.1016/j.nedt.2019.01.006

[34] Marshall, S., L., Ciarrochi, J., Parker, P., D., \& Sahdra, B., K. Is self-compassion selfish? The development of self-compassion, empathy, and prosocial behaviour in adolescence. Journal of Research on Adolescence, 30(s2), 472-484, 2020. https://doi.org/10.1111/jora.12492 
[35] Silke, C., Brady, B., Boylan, C., \& Dolan., P. Factors influencing the development of empathy and pro-social behaviour among adolescents: A systematic review. Children and Youth Services Review. 94, 421-436, 2018. https://doi.org/10.1016/j.childyouth.2018.07.027

[36] Aldridge, D. The Moral Contract, Sympathy and Becoming Human: A Response to Michael Hand's Theory of Moral Education. Journal of Philosophy of Education, 53(4), 636-641, 2019. https://doi.org/10.1111/1467-9752.12394

[37] Tillson, J. Sympathy, Social Stability and Those Left Out: Querying A Theory of Moral Education. Journal of Philosophy of Education, 53 (4), 649-655, 2019. https://doi.org/10.1111/ jope.v53.4

[38] Liu, L., Xu, L., Xiao, X., Liu, L., \& Li, Y. Positive influence of peers' interpersonal character on children's interpersonal character: The moderating role of children's and peers' social status. Journal of Adolescence, 79, 157-172, 2020. https://doi.org/10.1016/j.adolescence. $\underline{2020.01 .003}$

[39] Cameron, J., J., \& Granger, S. Does self-esteem have an interpersonal imprint beyond self-reports? A meta-analysis of self-esteem and objective interpersonal indicators. Personality and Social Psychology Review, 23(1), 73-102, 2019. https://doi.org/10.1177/ $\underline{1088868318756532}$

[40] Meagher, B., R. Ecologizing social psychology: The physical environment as a necessary constituent of social processes. Personality and Social Psychology Review, 24(1), 3-23, 2020. https://journals.sagepub.com/doi/pdf/10.1177/1088868319845938; https://doi.org/10.1177/ 1088868319845938

[41] Laguna, M., Mazur, Z., Kedra, M., \& Ostrowski, K. Interventions stimulating prosocial helping behavior: A systematic review. Journal of Applied Social Psychology, 50(11), 676-696, 2020. https://doi.org/10.1111/jasp.12704

[42] Genkova, P., Schreiber, H., \& Gade, M. Interculturality and social skills? Relationships of the stays abroad of students of different faculties with intercultural and social competence. Journal of Community and Applied Social Psychology, 31(4) 410-424, 2021. https://doi. org/10.1002/casp. 2513

[43] Ejimonye, J., C., Onuoha, J., C., Ugwuanyi, C., S., Eneogu, N., D., Ugwuanyi, B., E., \& Ogbuehu, S., N. Effectiveness of two-dimensional animation technique in enhancing students' motivation in quantitative economics concepts. International Journal of Future Generation Communication and Networking, 13(1), 27-38, 2020. https://doi.org/10.33832/ ijfgen.2020.13.1.03

[44] Wickramasinghe, M., H., M., \& Wickramasinghe, M., M., T. Impact of using 2D animation as a pedagogical tool. Psychology and Education, 58(1), 3435-3439, 2021. http://psychologyandeducation.net/pae/index.php/pae/article/view/1283/1080; https://doi.org/10.17762/ pae.v58i1.1283

[45] Agbaria, Q. Classroom management skills among kindergarten teachers as related to emotional intelligence and self-efficacy. International Journal of Instruction, 14(1), 1019-1034, 2021. https://doi.org/10.29333/iji.2021.14160a

[46] Tabaro, C. The Rwandan secondary school competence-based curriculum: Knowledge, skill and attitudes to incorporate in the University of Rwanda-College of Education Program to align them with the current curriculum. International Journal of Education and Practice, 6(2), 64-75, 2018. https://doi.org/10.18488/journal.61.2018.62.64.75

[47] Aminov, T., Magsumov, T., Sayakhov, R., Yepaneshnikov, V., Nasipov, I., \& Aitov, Valerie. Pedagogical potential of muslim religious sources in overcoming physical and mental and psychological trials. Journal of Social Studies Education Research, 9(2), 266-282. https:// jsser.org/index.php/jsser/article/view/260/253 
[48] Osipova, N., G., Elishev, S., O., Pronchev, G., B., \& Monakhov, D., N. Social and political portrait of contemporary Russian student youth. Journal of Social Studies Education Research, 9(1), 28-59, https://jsser.org/index.php/jsser/article/view/248/241

[49] Asiri, M., J. Do teachers attitudes, perception of usefulness, and perceived social influences predict their behavioral intentions to use gamification in EFL classrooms? Evidence from the Middle East. International Journal of Education and Practice, 7(3), 112-122, 2019. https://doi.org/10.18488/journal.61.2019.73.112.122

[50] Byongsam, J., Zheng, J., \& Park, G., Y. Factors affecting Korean military cadets attitude towards diversity. International Journal of Education and Practice, 8(2), 298-308. 2020. https://doi.org/10.18488/journal.61.2020.82.298.308

[51] Wohllebe, A., Hubner, D., S., \& Radtke, U. Smartphones and mobile apps: Case study on usage behavior of elementary school students. International Journal of Interactive Mobile Technologies, 15(12), 184-192, 2021. https://doi.org/10.3991/ijim.v15i12.22565

[52] Loannou, A., \& Timotheou, S. Collective creativity in STEAM making activities. The Journal of Education Research, 114(2), 130-138, 2021. https://doi.org/10.1080/00220671.2021. $\underline{1873721}$

[53] Alksasbeh, M., Abuhelaleh, M., Almaiah, M., A., Al Jaafreh, M., Karaka, A., A. Towards a model of quality features for mobile social networks apps in learning environments: An extended information system success model. International Journal of Interactive Mobile Technologies, 13(5), 75-93, 2019. https://doi.org/10.3991/ijim.v13i05.9791

[54] Al Kurdi, B., Alshurideh, M., Salloun, A., A., Obeidat, Z., M., \& Dweeri, R., M. An empirical investigation into examination of factors influencing university students' behavior towards e-learning acceptance using SEM approach. International Journal of Interactive Mobile Technologies, 14(2), 19-41, 2020. https://doi.org/10.3991/ijim.v14i02.11115

[55] Zhampeissova, K., Kosareva, I., \& Borisova, U. Collaborative mobile learning with smartphones in higher education. International Journal of Interactive Mobile Technologies, 14(21), 4-18, 2020. https://doi.org/10.3991/ijim.v14i21.18461

[56] Vaicondam, Y., Hishan, S., S., Begum, S., \& Hassan, M. Information and Communication Technology-based education planning and attitude of college students. International Journal of Interactive Mobile Technologies, 15(4), 48-60, 2021. https://doi.org/10.3991/ijim.v15i04. 20365

[57] Arwen, D., \& Puspita, D., R. The role of technology on students' character education. Journal of Physics: Conference Series, 1477, 1-5, 2020. https://doi.org/10.1088/1742-6596/ $1477 / 4 / 042070$

[58] Lin, X., F., Liang, J., C., Tsai, C., C., \& Hu, Q. The moderating role of self-regulated learning in job characteristics and attitudes towards web-based continuing learning in the airlines workplace. Australasian Journal of Educational Technology, 34(1), 102-115, 2018. https:// ajet.org.au/index.php/AJET/article/view/3198/1472; https://doi.org/10.14742/ajet.3198

[59] Mrabet, H., E., \& Moussa, A., A. IoT-school attendance system using RFID technology. International Journal of Interactive Mobile Technologies, 14(14), 95-108, 2020. https://doi. org/10.3991/ijim.v14i14.14625

[60] Lai, C., H., Jong, B., S., \& Hsia, Y., T. Using reminder tools to increase learning motivation: A comparison of mobile devices, email and e-learning platforms. International Journal of Interactive Mobile Technologies, 14(19), 82-96, 2020. https://doi.org/10.3991/ijim. v14i19.12519

[61] Zhampeissova, K., Kosareva, I., \& Borisova, U. Collaborative mobile learning with smartphones in higher education. International Journal of Interactive Mobile Technologies, 14(21), 4-18, 2020. https://doi.org/10.3991/ijim.v14i21.18461 
[62] Candiasa, I., M., Mertasari, N., M., S., \& Aryanta, M. Social media as integrated character education media. Journal of Physics: Conference Series, 1810, 1-6, 2021. https://doi. org/10.1088/1742-6596/1810/1/012073

[63] Tawafak, R., M., AlFarsi, G., Jabbar., Malik, S., I., Mathew, R., AlSidiri, A., Shakir, M., \& Romli, A. Impact of technologies during COVID-19 pandemic for improving behavior intention to use e-learning. International Journal of Interactive Mobile Technologies, 15(1), 184-198, 2021. https://doi.org/10.3991/ijim.v15i01.17847

[64] Vaicondam, Y., Hishan, S., S., Begum, S., \& Hassan, M. Information and Communication Technology-based education planning and attitude of college students. International Journal of Interactive Mobile Technologies, 15(4), 48-60, 2021. https://doi.org/10.3991/ijim. $\underline{\mathrm{v} 15 \mathrm{i} 04.20365}$

[65] Fisher, D., \& Kusumah, Y., S. Developing student character of preservice mathematics teachers through blended learning. Journal of Physics: Conference Series. 1132, 1-9, 2020. https://doi.org/10.1088/1742-6596/1132/1/012040

[66] Zabidi, N., \& Wang, W. The use of social media platforms as a collaborative supporting tool: A preliminary assessment. International Journal of Interactive Mobile Technologies, 15(6), 138-148, 2021. https://doi.org/10.3991/ijim.v15i06.20619

\section{$7 \quad$ Authors}

Arita Marini is a Professor from the Elementary School Teacher Education study program, Faculty of Education, Universitas Negeri Jakarta, Indonesia. She is also an assessor at the national accreditation body for higher education at the Ministry of Education, Culture, Research, and the Technology Republic Indonesia.

Desy Safitri is a lecturer with a doctoral degree from the Social Studies Education study program, Faculty of Social Science, Universitas Negeri Jakarta, Indonesia. She is also chief of this study program.

Ika Lestari is a lecturer with a doctoral degree from the Elementary School Teacher Education study program, Faculty of Education, Universitas Negeri Jakarta, Indonesia. She is also an evaluator for opening study programs at Higher Education in Indonesia.

Yustia Suntari is a lecturer with a master's degree from the Elementary School Teacher Education study program, Faculty of Education, Universitas Negeri Jakarta, Indonesia. His main research interest is related to education at elementary schools. She is studying at Universitas Negeri Jakarta to get a doctoral degree.

Sri Nuraini is a senior lecturer with a doctoral degree in Sports Science, Sports Recreation and Sport Education study program, Faculty of Sports Science, Universitas Negeri Jakarta, Indonesia. Her main research interest is related to Sport Science, Sports Recreation, and Sport Education.

Maratun Nafiah is a senior lecturer with a doctoral degree from the Elementary School Teacher Education study program, Faculty of Education, Universitas Negeri Jakarta, Indonesia. She has done many kinds of researches related to education, especially for assessments at elementary schools.

Saipiatuddin is a lecturer with a master's degree from the Social Studies Education study program, Faculty of Social Science, Universitas Negeri Jakarta, Indonesia. Her main research interest is education. 
Wahyu Sri Ambar Arum is a senior lecturer with a doctoral degree from the Educational Management study program, Faculty of Education, Universitas Negeri Jakarta, Indonesia. She actively does many kinds of researches related to managing schools.

Ajat Sudrajat is a lecturer with a doctoral degree from the Civics Education study program, Faculty of Teacher Training and Education, Universitas Negeri Terbuka, Indonesia. He is also an assessor of elementary schools in Indonesia.

Rossi Iskandar is a lecturer from the Elementary School Teacher Education study program, Faculty of Education, Universitas Trilogi, Jakarta, Indonesia. He is studying at Universitas Negeri Jakarta to get a doctoral degree.

Article submitted 2021-06-20. Resubmitted 2021-08-09. Final acceptance 2021-08-11. Final version published as submitted by the authors. 